\title{
Phosphorus Kinetics in Calves Submitted to Single Infection with Cooperia punctata
}

\author{
Louvandini H. (Corresponding author) \\ Faculty of Agronomy and Veterinary Medicine, University of Brasília \\ PO Box 04508, 70910-970, Brasília, DF, Brazil \\ E-mail: hlouvand@unb.br
}

Rodrigues, R. R.

Animal Nutrition Laboratory, Centre of Agricultural Nuclear Energy, University of São Paulo

PO Box 96, 13400-970, Piracicaba, SP, Brazil

E-mail: vitti@cena.usp.br

Gennari, S. M.

Faculty of Medicine Veterinary and Zootech ny, University of São Paulo

Orlando Marques de Paiva, 87, Cidade Universitária, 05508-900, São Paulo, SP, Brazil

E-mail: sgennari@usp.br

McManus C.M.

Faculty of Agronomy and Veterinary Medicine, University of Brasília

PO Box 04508, 70910-970, Brasília, DF, Brazil

E-mail: concepta@unb.br

Vitti, D. M. S. S.

Animal Nutrition Laboratory, Centre of Agricultural Nuclear Energy, University of São Paulo

PO Box 96, 13400-970, Piracicaba, SP, Brazil

E-mail: vitti@cena.usp.br

The research is financed by FAPESP (project number-00/00640-0) and CNPq for the research scholarships of the authors.

\begin{abstract}
The aim of this study was to evaluate phosphorus (P) kinetics in calves submitted to a single acute infection of Cooperia punctata, using isotopic dilution and modelling techniques. Ten Holstein calves were used, with a mean live weight of $66.05 \pm 0.30 \mathrm{~kg}$. Of these, five received a single dose of 45000 infectant $\left(\mathrm{L}_{3}\right)$ C. punctata larvae and the other five were maintained in a control group without infection. Twenty one days after the infection, all animals received 29.6 $\mathrm{MBq}^{32} \mathrm{P}$ by intravenous injection to evaluate $\mathrm{P}$ kinetics. Weight gain, feed consumption and excretion in the faeces and urine were monitored and blood was collected for seven days. After the collection period, all animals were slaughtered,
\end{abstract}


tissues collected and worms counted. The number of eggs per gram of faeces (EPG) reached $3342 \pm 194$ and the number of adult worms was $12992 \pm 1$ 470. Final live weight, mean daily live weight gain, level of P in the plasma and its retention in control calves were higher and $\mathrm{P}$ excretion in the faeces less than in the infected calves. There was a negative $\mathrm{P}$ balance in both the control and infected calves for soft tissues and bone. A single infection by C. punctata negatively influenced calf performance and $\mathrm{P}$ kinetics, leading to lower retention of the mineral.

Keywords: Cattle, Mineral, Modelling, Parasite

\section{Introduction}

Cooperia sp. is one of the most prevalent nematodes of cattle in Brazil and C. punctata present the highest occurrence (Lima, 1998). A high level infection with this nematode may lead to nutritional deficiencies or worsen those that already exist. Vieira-Bressan et al. (1996) found a reduction in fat-free body weight, total body water and nitrogen retention in calves infected with $C$. punctata.

Despite the high prevalence of C. Punctata, few studies are available correlating the physiopathology of the infection (Yatsuda and Vieira-Bressan, 2000) especially those with that involve mineral metabolism. Phosphorus (P) is of particular interest due to the functions it serves in the organism, such as involvement in different metabolic activities and bone composition, among others. Its deficiency in ruminants has been widely discussed in herds kept at pasture (Underwood \& Suttle, 1999).

C. punctata lives in the small intestine (duodenum and jejunum), which is also the location of highest $\mathrm{P}$ absorption (Schröder et al., 1995). When the parasite penetrates the intestinal wall, it causes not only diarrhea and emaciation, but can also interfere with mineral metabolism. This interference was observed with Trichostrongylus colubriformis, which infects the same space in the intestine of sheep (Bown et al., 1989).

Vitti et al. (2000) elaborated a model to evaluate P kinetics in goats. The P metabolism in cattle has been studied using radioisotopes by Silva Filho et al. (2000) and Vitti et al. (2001). This study aimed to evaluate P kinetics in calves infected with a single dose (45 000 infective larvae) of Cooperia punctata, using isotopic dilution and modelling techniques.

\section{Materials and Methods}

\subsection{Animals and diets}

Ten Holstein calves, acquired at two days of age, were kept in the Department of Preventive Veterinary Medicine and Animal Health (VPS) of the Faculty of Veterinary Medicine and Zootechny (FMVZ) of the University of São Paulo (USP) at the Pirassununga Campus, São Paulo State, Brazil. The experimental protocol was approved by the University Ethics Committee of Animal Experimentation.

The calves were bottle fed on in natura milk and kept in collective stalls with cement floors until weaning at two months of age. After this they received a daily ration of $1500 \mathrm{~g}$ of Coast-cross (Cynodon dactilon) hay and $1000 \mathrm{~g}$ of commercial concentrate to meet requirements defined by the National Research Council (NRC, 2001), as well as water ad libitum (Table 1).

\subsection{Infection, radioactive and sampling method}

Five calves received a single dose of $45000 \mathrm{~L}_{3}$ C. punctata larvae and five remained without infection (control). After larval innoculation the animals were housed in individual cages for metabolic study for 28 days. The adaptation period lasted 21 days and the following seven days were used for sample collection. On the $22^{\text {nd }}$ day each animal was intravenously injected with $29.6 \mathrm{MBq}$ of a ${ }^{32} \mathrm{P}$ solution. Blood samples $(10 \mathrm{~mL})$ were taken by vacutainer from the left jugular vein at $24 \mathrm{~h}$ intervals for seven days after the isotope administration. Blood was centrifuged and plasma separated for analysis. Trichloroacetic acid $(9 \mathrm{~mL})$ was added to $1 \mathrm{~mL}$ of plasma for protein precipitation. After centrifugation $(1100 \times \mathrm{g})$, inorganic $\mathrm{P}$ was determined by colorimetric analyses (Fiske \& Subbarow, 1925).

$\mathrm{P}$ intake and excretion in faeces and urine were recorded for 7 days, and subsamples (10\% of total outputs) were stored at $4{ }^{\circ} \mathrm{C}$. Faeces samples $(1 \mathrm{~g})$ were dried overnight $\left(105^{\circ} \mathrm{C}\right)$ and ashed $\left(500{ }^{\circ} \mathrm{C}\right.$ for $\left.8 \mathrm{~h}\right)$. P content was determined by a colorimetric method (Sarruge \& Haag, 1974). A similar procedure was used to determine P content in the consumed feed. Urine samples $(30 \mathrm{~mL})$ were acidified by using $100 \mathrm{~mL}$ of $12 \mathrm{~N} \mathrm{HCl}$, then dried $\left(55^{\circ} \mathrm{C}\right)$ and ashed $\left(500{ }^{\circ} \mathrm{C}\right)$. Inorganic P was determined using vanadate-molybdate reagents (Sarruge \& Haag, 1974). For radioactivity measurements, $1 \mathrm{~mL}$ plasma and urine samples were added to $19 \mathrm{~mL}$ of distilled water in counting vials. Ashed fecal samples $(1 \mathrm{~g})$ were dissolved in $18 \mathrm{~N} \mathrm{H}_{2} \mathrm{SO}_{4}$. Radioactivity of ${ }^{32} \mathrm{P}$ was measured by using Cerenkov radiation.

Specific activities in plasma and faeces were determined according to Lofgreen and Kleiber (1953). After the end of the collection period, the calves from both groups were slaughtered by $5 \mathrm{~mL} . \mathrm{kg}-1$ intravenous injection of mebezonic iodine, embutramide and tetracaine cloridrate. Tissues (liver, heart, kidney, and muscles) and bone samples (12 ${ }^{\text {th }}$ rib) were collected from three calves from each group. The material was cleaned, weighed, and autoclaved. Samples were ground 
and dissolved in $18 \mathrm{~N} \mathrm{H}_{2} \mathrm{SO}_{4}$. The extract was transferred to vials for radioactivity determination. For P determination, bone samples were dissolved in concentrated $\mathrm{HCl}$ (Sarruge \& Haag, 1974). Bone specific activity in $1 \mathrm{~g} \mathrm{DM}$ and ${ }^{32} \mathrm{P}$ incorporation in bone were calculated according to Lofgreen \& Kleiber (1953).

\subsection{Parasitological Exam}

Worm infection was monitored by faecal examination (eggs per gram of faeces, EPG), using the modified McMaster method (Leland, 1995). This was carried out daily until the 14th day after infection until the patency period. After this phase, faeces samples for each calf were examined weekly until the ${ }^{32} \mathrm{P}$ injection. After the injection the faeces became radioactive, and therefore were no longer used for EPG counting. Blood samples were collected weekly for determination of $\mathrm{P}$, total protein and serum albumin.

At necropsy, the contents of the small intestine and mucosal scrapings were washed with running water and the volume made up to $2 \mathrm{~L}$ with water. After mixing, duplicate $200 \mathrm{~mL}$ samples $(10 \%)$ were collected and preserved in $10 \%$ formalin for total worm counts and identification of larval stages. To release the worms which were adhered to the mucosa, the small intestine was incubated in distilled water at $32.8{ }^{\circ} \mathrm{C}$ for $24 \mathrm{~h}$. After this period, the intestine was removed and the total contents preserved in $10 \%$ formalin for worm identification and counting.

\subsection{Mathematical model}

The model proposed by Vitti et al. (2000) was used for P kinetics evaluation. The representation of the kinetic model with radioisotopes is in Figure 1. The differential equations which describe the behaviour of the kinetics of the model are based on the principles of mass conservation. The system is assumed to be in partial equilibrium and the solutions for differential equations were obtained by equaling them to zero and manipulating them to obtain expressions of individual flows of interest. The symbols in Figure 1 represent the following equations:

$$
\begin{gathered}
F_{12}=s_{1} \tilde{F}_{10} /\left(s_{2}-s_{1}\right), \\
F_{21}=\widetilde{F}_{10}+F_{12}-\widetilde{F}_{01}, \\
F_{32}=s_{3} Q_{3} /\left[t\left(s_{2}-s_{3}\right)\right], \\
F_{42}=s_{4} Q_{4} /\left[t\left(s_{2}-s_{4}\right)\right], \\
\left|F_{23}+F_{24}\right|=\tilde{F}_{02}+F_{12}+F_{32}+F_{42}-F_{21}, \\
F_{24}=\left(s_{3+4}-s_{3}\right)\left|F_{23}+F_{24}\right| /\left(s_{4}-s_{3+4}\right), \\
F_{23}=\left|F_{23}+F_{24}\right|-F_{24},
\end{gathered}
$$

where, $\mathrm{F}(\mathrm{g} /$ day) represents flow, $\mathrm{s}(\mathrm{dpm} / \mathrm{g} \mathrm{P})$ is the specific radioactivity activity on tissues, $\mathrm{t}$ (day) is the time from the start of the experiment until the count and $\mathrm{Q}(\mathrm{g})$ is the total content of $\mathrm{P}$ in a certain compartment. The notation $\mathrm{s} 3+4$ represents the mean specific activity in compartments 3 and 4 .

The total endogenous $P$ in the faeces was calculated as:

$$
\mathrm{F}_{\mathrm{e} 01}=\mathrm{F}_{12} \mathrm{~F}_{01} /\left(\mathrm{F}_{12}+\mathrm{F}_{10}\right)=\mathrm{s}_{1} \mathrm{~F}_{01} / \mathrm{s}_{2}
$$

where $\mathrm{F}_{10}$ is the consumption of $\mathrm{P}$ and $\mathrm{F}_{01}$ the $\mathrm{P}$ in the faeces.

The true absorption of $\mathrm{P}$ was calculated as

\subsection{Statistical analysis}

$$
\mathrm{F}_{\mathrm{abs}}=\mathrm{F}_{10}-\left(\mathrm{F}_{01}-\mathrm{F}_{\mathrm{e} 01}\right) \text {. }
$$

Experimental measurements were analyzed in a completely randomized design. For flow data three calves were used to minimize manipulation of radioactive samples. A comparison of means between each treatment was carried out using the General Linear Model (GLM) procedure (SAS, 2000). Treatment means were assessed using the least significant difference method when overall treatment effects were $\mathrm{P}<0.10$.

\section{Results and discussion}

The infected calves showed softened faeces, and two animals manifested diarrhea with a more liquid faeces, as well as depression and teeth grinding, suggesting abdominal discomfort and/or a painful process. The mean EPG counts from week 0, 1, 2, 3 and 4 after infection were: $0,0,80 \pm 20,2000 \pm 398$ and $3342 \pm 435$. The mean of total adult $C$. punctata number was $12992 \pm 1470$ and of immature forms were $289 \pm 76$. According to Ueno \& Gonçalves (1998), an infection by Cooperia sp. is considered severe when animals show an EPG and parasite number greater than 200 and 10000 respectively. Despite the higher EPG (3 342) and worm burden (12 992) the calves here showed only softened faeces, which were runny in only two animals, soon after infection, and these animals recovered in a few days, indicating a moderate infection. This was confirmed by the values of the total protein and albumin, which still in the normal range. 
Mean values of dry matter (DM) and $\mathrm{P}$ intake, performance, plasmatic (total protein, albumin and $\mathrm{P}$ ), as well as variables related to $\mathrm{P}$ metabolism, for control and infected groups, are shown in Table 2. Final live weights, mean daily weight gain, $\mathrm{P}$ level in plasma and $\mathrm{P}$ retention in the control group were higher than the infected group. $\mathrm{P}$ excretion in faeces was higher in the infected group. No significant differences were found between groups for DM and P intake, total protein, albumin, endogenous $\mathrm{P}$ in faeces and biological availability. No reduction in feed intake was observed in this study, even though this is one of the symptoms associated with infection by Cooperia sp. (Armour et al., 1987). This indicates that the effects found on $\mathrm{P}$ metabolism are directly related to the influence of the parasites on the nutrients in the diet. The control calves showed higher weight gains, P levels in the plasma and its retention, with lower $\mathrm{P}$ excretion in the faeces. This negative effect on utilization of the diet and in particular of $\mathrm{P}$ utilization due to an acute infection of C. punctata is therefore evident.

For both treatments, means were within the normal range for the plasma P (4 to $8 \mathrm{mg} .100 \mathrm{~mL}^{-1}$ ) for young bovines (Rosemberger, 1979), but lower values were observed in infected calves. This decrease was also reported by Coop \& Field (1983), who observed a fall in plasma $\mathrm{P}$ in lambs experimentally infected by $T$. vitrinus, from the $8^{\text {th }}$ week of infection. Oliveira (2000) observed a marked decrease in plasmatic P of calves experimentally infected with $150000 \mathrm{~L}_{3}$ C. punctata, a higher number than used in the present study. Such losses may be related to the plasma flow through mucosal injuries caused by parasites, reported by authors that have studied T. columbriformis infections (Holmes, 1985; Poppi et al., 1986).

The biological availability values were high for both treatments (control $=85.54 \%$ and infected $=76.53 \%$ ), being above the $70 \%$ level indicated by the NRC (2001). This uses the premise that biological availability is a trait associated with the feed, not taking into consideration the interaction of the animal with this variable, thereby using estimates.

It was seen that the P metabolism in young animals was directed towards ensuring growth, indicating the need for an efficient system of mineral absorption. As a high availability of $\mathrm{P}$ was observed, the value of $\mathrm{P}$ excreted in the faeces was on average 43.93 and $30.17 \%$ of the total consumed for the control and infected treatments, respectively. These values are low if compared to literature values. Silva Filho et al. (2000) showed that excreted P in the faeces in ruminants corresponded to $70 \%$ of consumed $\mathrm{P}$. The $\mathrm{P}$ excreted in the faeces of infected animals have was approximately 1.7 times higher than $\mathrm{P}$ in the faeces of control animals, again indicating the interference of $C$. punctata in the use of this mineral.

Retention is the best indicator of mineral use. For control calves this was $8.68 \mathrm{~g} \mathrm{P} / \mathrm{day}$, compared with $6.97 \mathrm{~g} \mathrm{P} /$ day for infected calves. Although calves on both treatments showed positive P retention, the details of where this mineral is absorved and used was only possible with the quantification of P flows using radioisotopes. Although no significant differences were found in terms of endogenous loss and $\mathrm{P}$ absorption between healthy and infected calves, these seem to be the main mechanisms in the explanation for greater $\mathrm{P}$ in faeces and lower retention in infected calves.

P flow results between compartments are shown in Table 3. No significant differences were found between groups for these, due to the low number of calves used and higher standard error observed. Using this information, it was possible to quantify that the main destination of $\mathrm{P}$ was the central compartment (blood), represented by the readily available labeled form of the mineral, responsible for the maintenance of homeostasis in the animal organism, followed by bone tissue and finally soft tissues. Even in the control calves, P balance in the soft tissues and bone was negative, but guaranteed a growth rate of $190 \mathrm{~g} /$ day. This is low and was affected by quantity and quality of roughage offered. It should be noted that the proposed diet is in agreement with average diet intake for this type of animal on-farm in Brazil.

Although no significant differences were found in P flows between control and infected calves, the balance of $\mathrm{P}$ in bone tissue for the control group was negative $(-0.53 \mathrm{~g} /$ day $)$ and for the infected calves $(-1.06 \mathrm{~g} /$ day $)$. This showed, once again, the interference of the acute infection of C. punctata on P metabolism and placing bone tissue as the main mineral reserve used when this mineral is required by the animal. In a similar experiment, but with chronic infection of $10000 \mathrm{~L}_{3}$ per week during five weeks, the P metabolism was negatively affected the P kinetics, as a consequence of lower DM and P intake, as well as $\mathrm{P}$ retained. This led, more specifically, to weight loss, indicating a more severe process (Louvandini et al., 2009).

Studies in young sheep have shown that growth of bone tissue is guaranteed in detriment of adequate mineralization, leading to formation of bone with less maturity (Nicodemo et al., 1999), but maintained the animal development, as well as ensuring the vital functions for which $\mathrm{P}$ is essential. Therefore, the fact that calves gained weight is justified, despite the negative tissues balances. Bone and soft tissues are involved in this process, validating the hypothesis where mobilization of nutrients in young animals is directed towards growth. Nevertheless, this observation questions the P recommendation made by NRC (2001) for calves of about $100 \mathrm{~kg}$ body weight at $0.31 \%$ of DM intake, i.e. 8.3 g.d $\mathrm{d}^{-1}$ which was used to formulate the diet in this trial. Results here indicate that recommendations may not guarantee ideal deposition of $\mathrm{P}$ in the tissues (soft and bone). An acute infection by C. punctata negatively affected calf performance and $\mathrm{P}$ kinetics, increasing its excretion in the faeces and reducing its retention. 


\section{References}

Armour, J., Bairden, K., Holmes, P.H., Parkins, J.J., Ploeger, H., Salman, S.K. \& Mcwilliam, P.N. (1987). Pathophysiological and parasitological studies on Cooperia oncophora infections in calves. Research in Veterinary Science, 42, 373-381.

Bown, M.D., Poppi, D.P. \& Sykes, A.R. (1989). The effects of a concurrent infection of Trichostrongylus colubriformis and Ostertagia circumcincta on calcium, phosphorus and magnesium transactions along the digestive tract of lambs. Journal of Comparative Pathology, 101, 12-20.

Coop, R.L. \& Field, A.C. (1983). Effect of phosphorus intake on growth rate, food intake, and quality of the skeleton of growing lambs infected with the intestinal nematode Trichostrongylus vitrinus. Research in Veterinary Science, 35, $175-181$.

Fiske, C. H. \& Subbarow, Y. (1925). The colorimetric determination of phosphorus. Journal of Biological Chemistry, $66,375-400$.

Holmes, P. H. (1985). Pathogenesis of trichostrongylosis. Veterinary Parasitology, 18, 89-101.

Leland, S.E. (1995). Monospecific nematode infections of donor calves with Cooperia punctata. Veterinary Parasitology, 60,111-118.

Lima, W.S. (1998). Seasonal infection pattern of gastrointestinal nematodes of beef cattle in Minas Gerais State - Brazil. Veterinary Parasitology, 74, 203-214.

Lofgreen, G.P. \& Kleiber, M. (1953). The availability of the phosphorus in alfafa hay. Journal of Animal Science, 12, 366-371.

Louvandini, H., Rodrigues, R.R., Gennari, S.M., Mcmanus, C.M., Vitti, D.M.S.S. (2009). Phosphorus kinetics in calves experimentally submitted to a trickle infection with Cooperia punctata. Veterinary Parasitology, 163, 47-51.

Oliveira, R.O. (2001). Estudo da inter-relação parasito-hospedeiro em bovinos infectados com Cooperia punctata. Efeito da suplementação protéica sobre as alterações fisiopatológicas em bezerros com infecção única. Instituto de Ciências Biomédicas, Universidade de São Paulo, 127p

Poppi, D.P., MacRae, J.C., Brewer, A. \& Coop, R.L. (1986). Nitrogen transactions in the digestive tract of lambs exposed to the intestinal parasite Trichostrongylus colubriformis. British Journal of Nutrition, 55, 593-602.

Nicodemo, M.L., Scott, D., Buchan, W., Ducan, A. \& Robins, S.P. (1999). Effects of variations in live weight gain on bone growth and composition and on markers of bone turnover in lambs. Experimental Physiology, 84, $579-587$.

Rosemberger, G. (1979). Clinical examination of cattle. Berlin, Verlag Paul Parey, 136.

NRC. (2001). Nutrient requeriments of dairy cattle. 7th revised edition. Washington, D.C.: National Academic Press.

Sarruge, J. R. \& Haag, H. P. (1974). Análises químicas em plantas. In Determinação colorimétrica do fósforo, pp. 6-58. Piracicaba: ESALQ, Departamento de Química.

Schöder, B., Käppner, H., Failing, K., Pfeffer, E. \& Breves, G. (1995). Mechanisms of intestinal phosphate transport in small ruminants. British Journal of Nutrition, 74, 635-648.

Silva Filho, J.C., Vitti, D.M.S.S., Campos Neto, O. \& Abdalla. A.L. (2000). Exigência mínima de fósforo em novilhos da raça nelore. Pesquisa Agropecuária Brasileira, 35, 1861-1865.

SAS Institute Inc. (2000). SAS/STAT User's Guide version 8. Cary, North Carolina: SAS Institute Inc.

Ueno, H. \& Gonçalves, P.C. (1998). Manual para diagnósticos das helmintoses de ruminantes, fourth ed. Press Color, $143 \mathrm{p}$

Underwood, E.J. \& Suttle, N.F. (1999). The mineral nutrition of livestock. 3.ed. Wallingford: CAB International, p. 180

Vieria-Bressan, M.C.R., Gennari, S.M., Abdalla, A.L. \& Santos Filho, J.P. (1996). Body composition, water and nitrogen balance in calves infected with Cooperia punctata. Revista Brasileira de Parasitologia Veterinária, 5, 75-79.

Vitti, D. M. S. S., Kebreab, E., Lopes, J. B., Abdalla, A. L., Carvalhos, F. F. R., Resende, K. T., Crompton, L. A. \& France, J. (2000). A kinetic model of phosphorus metabolism in growing goats. Journal of Animal Science, 78, 2706-2712.

Vitti, D.M.S.S., Lopes, J.B., Abdalla, A.L., Silva Filho, J.C., Abdalla, A.L. \& Haddad, M. (2001). Fluxo de fósforo (P) de diferentes fontes de fosfato em bovinos. Arquivo Brasileiro de Medicina Veterinária e Zootecnia, 53, $218-223$.

Yatsuda, A.P. \& Vieira-Bressan, M.C.R. (2000). Dynamics of the humoral immune response of calves infected and re-infected with Cooperia punctata. Veterinary Parasitology, 87, 287-300. 
Table 1. Chemical composition of diet received by calves

\begin{tabular}{lcc}
\hline $\begin{array}{l}\text { Chemical composition } \\
\text { (g/kg dry matter) }\end{array}$ & Hay & Concentrate \\
& & \\
& & \\
\hline Dry matter & 915.63 & 923.72 \\
Crude protein & 75.82 & 153.15 \\
Neutral detergent fibre & 762.09 & 256.86 \\
Ether extract Acid & 403.75 & 93.11 \\
detergent fibre & 20.85 & 105.53 \\
Ash & 57.10 & 83.39 \\
Phosphorus & 1.78 & 10.81 \\
\hline \hline
\end{tabular}

Table 2. Intake, performance, plasma and P metabolism in control and calves infected with single dose of $45000 \mathrm{~L}_{3}$ of C. punctata

\begin{tabular}{|c|c|c|c|c|}
\hline \multirow[t]{2}{*}{ Variables } & \multicolumn{2}{|c|}{ Treatments } & \multirow[t]{2}{*}{$\mathrm{se}^{*}$} & \multirow[t]{2}{*}{ Probability } \\
\hline & $\begin{array}{c}\text { Control } \\
(n=5)\end{array}$ & $\begin{array}{l}\text { Infected } \\
\qquad(\mathrm{n}=5)\end{array}$ & & \\
\hline Dry matter intake $\left(\mathrm{g} \cdot \mathrm{d}^{-1}\right)$ & 2,297 & 2,297 & 0.06 & 0.71 \\
\hline$P$ intake $\left(\mathrm{g} . \mathrm{d}^{-1}\right)$ & 12.43 & 12.43 & 0.0004 & 0.71 \\
\hline Live weight initial $(\mathrm{kg})$ & 66.30 & 65.80 & 1.58 & 0.80 \\
\hline Live weight final $(\mathrm{kg})$ & $70.30^{\mathrm{a}}$ & $68.10^{\mathrm{b}}$ & 0.61 & 0.03 \\
\hline Dairy gain $\left(\right.$ g. $\left.\mathrm{d}^{-1}\right)$ & $190.5^{\mathrm{a}}$ & $109.5^{\mathrm{b}}$ & 29.35 & 0.10 \\
\hline Plasma P (mg . $\left.100^{-1} \mathrm{~mL}\right)$ & $7.80^{\mathrm{a}}$ & $6.18^{\mathrm{b}}$ & 0.50 & 0.05 \\
\hline Total protein $\left(\mathrm{g} \cdot 100^{-1} \mathrm{~mL}\right)$ & 6.5 & 6.1 & 0.35 & 0.36 \\
\hline Albumin $\left(\mathrm{g} \cdot 100^{-1} \mathrm{~mL}\right)$ & 3.5 & 3.6 & 0.35 & 0.78 \\
\hline Endogenous $\mathrm{P}$ in faeces $\left(\mathrm{g} \cdot \mathrm{d}^{-1}\right)$ & 1.80 & 2.60 & 0.41 & 0.31 \\
\hline P absorbed $\left(\mathrm{g} \cdot \mathrm{d}^{-1}\right)$ & 10.66 & 9.51 & 0.54 & 0.15 \\
\hline P excreted in faeces $\left(\mathrm{g} \cdot \mathrm{d}^{-1}\right)$ & $3.75^{\mathrm{b}}$ & $5.46^{\mathrm{a}}$ & 0.65 & 0.08 \\
\hline$P$ retained $\left(\mathrm{g} \cdot \mathrm{d}^{-1}\right)$ & $8.68^{\mathrm{a}}$ & $6.97^{\mathrm{b}}$ & 0.64 & 0.09 \\
\hline Biological availability (\%) & 85.54 & 76.53 & 4.15 & 0.13 \\
\hline
\end{tabular}

* standard error, ${ }^{\text {a and b }}$ Means with different letters in the same row were significantly different $(\mathrm{P}<0.10)$ 
Table 3. P flow in control and calves infected with a single dose of 45000 L3 of C. punctata

\begin{tabular}{|c|c|c|c|c|}
\hline \multirow[t]{2}{*}{ Variables (P/g/day) } & \multicolumn{2}{|c|}{ Treatments } & \multirow[t]{2}{*}{ se* $^{*}$} & \multirow[t]{2}{*}{ Probability } \\
\hline & $\begin{array}{l}\text { Control } \\
(n=3)\end{array}$ & $\begin{array}{l}\text { Infected } \\
\quad(n=3)\end{array}$ & & \\
\hline $\mathrm{P}$ intake $\left(\mathrm{F}_{10}\right)$ & 12.43 & 12.43 & 0.0002 & 0.59 \\
\hline$P$ faeces $\left(\mathrm{F}_{01}\right)$ & 3.41 & 4.83 & 2.33 & 0.30 \\
\hline $\mathrm{P}$ urine $\left(\mathrm{F}_{02}\right)$ & 0.00 & 0.00 & - & - \\
\hline P blood to GIT** $\left(\mathrm{F}_{12}\right)$ & 11.09 & 11.53 & 1.65 & 0.63 \\
\hline P GIT to blood $\left(F_{21}\right)$ & 20.11 & 19.13 & 2.56 & 0.50 \\
\hline $\mathrm{P}$ blood to bone $\left(\mathrm{F}_{32}\right)$ & 3.64 & 2.68 & 1.27 & 0.56 \\
\hline $\mathrm{P}$ bone to blood $\left(\mathrm{F}_{23}\right)$ & 4.17 & 3.74 & 2.96 & 0.56 \\
\hline $\mathrm{P}$ bone balance & -0.56 & -1.06 & 0.80 & 0.57 \\
\hline $\mathrm{P}$ blood to soft tissues $\left(\mathrm{F}_{42}\right)$ & 0.44 & 0.37 & 0.34 & 0.88 \\
\hline $\mathrm{P}$ soft tissues to blood $\left(\mathrm{F}_{24}\right)$ & 0.78 & 0.81 & 0.40 & 0.76 \\
\hline P soft tissues balance & -0.34 & -0.44 & 0.14 & 0.78 \\
\hline
\end{tabular}

* standard error; ** gastrointestinal tract; ${ }^{\mathrm{a} \text { and } \mathrm{b}}$ Means with different letters in the same row were significantly different $(\mathrm{P}<0.10)$ 


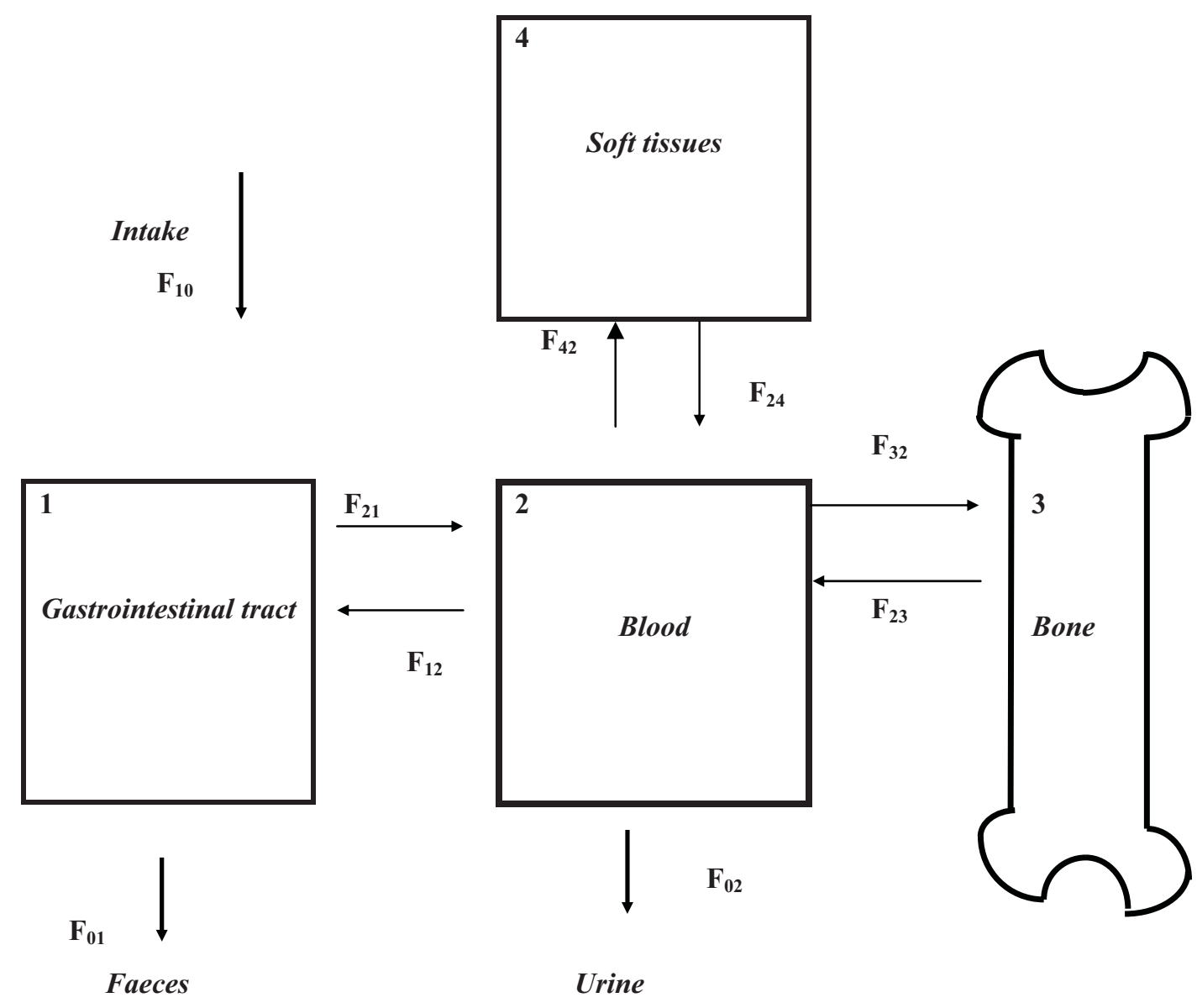

Figure 1. Schematic mathematical model for phosphorus (P) metabolism in calves, adapted from Vitti et al. (2000). Legend: $\mathrm{P}$ intake $\left(\mathrm{F}_{01}\right)$, P flow blood to gastrointestinal $\left(\mathrm{F}_{12}\right), \mathrm{P}$ in faeces $\left(\mathrm{F}_{01}\right), \mathrm{P}$ in urine $\left(\mathrm{F}_{02}\right)$, absorbed dietary $\mathrm{P}\left(\mathrm{F}_{21}\right)$, P flow blood to bone $\left(\mathrm{F}_{32}\right)$, P flow bone to blood $\left(\mathrm{F}_{23}\right)$, P flow blood to soft tissues $\left(\mathrm{F}_{42}\right)$ and $\mathrm{P}$ flow soft tissues to blood $\left(\mathrm{F}_{24}\right)$ 